\title{
Montenegrin Journal of Economics
}

Vol. 15, No. 3 (2019), 137-153

\section{Economic Security Management of Ukraine in Conditions of European Integration}

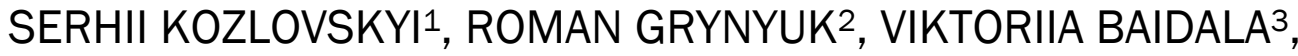 VIRA BURDIAK ${ }^{4}$ and YURIY BAKUN 5}

1 Professor, Vasyl' Stus Donetsk National University, Department of Entrepreneurship, Corporate and Spatial Economics, Vinnytsia, Ukraine, e-mail: s.kozlovskyy@donnu.edu.ua

2 Professor, Vasyl' Stus Donetsk National University, Rector, Vinnytsia, Ukraine, e-mail: grinuk@donnu.edu.ua

3 Professor, National University of Life and Environmental Sciences of Ukraine, Department of Economic Theory, Kyiv, Ukraine, e-mail: baidalavika@gmail.com

4 Professor, Yuriy Fedkovych Chernivtsi National University, Department of Political Science and Public Administration, Chernivtsi, Ukraine, e-mail: v.burdjak@chnu.edu.ua

5 Doctoral candidate, National University of Life and Environmental Sciences of Ukraine, Kyiv, Ukraine, e-mail:y_bakun@ukr.net

\section{ARTICLE INFO}

Received February 27, 2019

Revised from March 25, 2019

Accepted April 27, 2019

Available online September 15, 2019

\section{JEL classification:}

F15, 011.

DOI: 10.14254/1800-5845/2019.15-3.10

Keywords:

European Union, integration,

threats to economic security, innovative development, public administration.

\begin{abstract}
In conditions of political and economic transformation in Ukraine accompanied by decentralization of all aspects of public life, the function of ensuring national security of the country is allocated as an independent administrative function of the state, since it requires centralized state management. The aim of the study is to determine the main factors influencing the provision of economic security, and the improvement of the mechanism for managing the economic security of Ukraine in the context of European integration. The article proves that increasing the level of the economic security of the state is possible on the basis of improving state regulation of economic growth through the development of conceptual and program documents of interregional and territorial planning, and the creation of a comprehensive risk control system. To implement this, it is necessary to: conduct an active state anti-inflation, currency, exchange rate, monetary and fiscal policy focused on import substitution and support of the real economy; stimulating and supporting the development of the market for innovation, high-tech products and products with high added value. It is proved that the innovative model of economic development based on the strategy of institutional market transformation oriented to the formation of the innovative model of economic development can provide Ukraine with competitive advantages among developed countries, realize its national interests in the field of international economic relations and provide the necessary level of economic security.
\end{abstract}




\section{INTRODUCTION}

In current conditions it is very important to formulate and implement a policy that is, on the one hand, adequate to the objective place and role of Ukraine in the world community, and on the other hand, capable of resisting real threats to its national interests and security. A special attention should be paid to the economic security of Ukraine, since the domestic volatility of the economy now increasingly depends on the country's competitiveness in world markets.

External threats to economic security in the Ukrainian economy are getting more important than they used to be. In conditions of European integration of Ukraine, there are contradictions in economic development caused by both a change in the balance of forces in the economic arena and the need for an internal innovation restructuring of the national economy to achieve a greater competitiveness. The leading role should belong to the state long-term strategies to manage the economic transition to an innovative path of development in the face of increasing international competition.

Ukraine faced a choice of one of three basic strategies of institutional transformation: the strategy of market-bureaucratic modernization, the strategy of liberal fundamentalism and the strategy of the intuitional-market transformation, aimed at the formation of an innovative model of economic development. In conditions of European integration, only an innovative model of economic development can provide the country with competitive advantages among developed countries, realize its national interests in the sphere of international economic relations and ensure the necessary level of internal and external economic security.

One of the objective trends in Ukraine's modern economy is European integration, that is, the formation and further strengthening of ties with the countries of Europe at all levels: interstate, interregional, and between individual economic actors. European integration has a complex nature - economic, political, social, cultural, etc. Today, European integration is a strategic course of Ukraine, and its speed is growing. It obliges to pay attention to the consequences of European integration, in particular for the economic security of the state as a whole. The lack of a systematic approach in forming the strategic directions of international cooperation leads to inconsistencies between economic priorities, identified by government programs, and strategic goals of ensuring Ukraine's economic security. Priority directions of European integration of Ukraine, declared in international agreements, are not always based on competitive advantages and do not take into account the competitiveness of the domestic economy, strengthening institutional threats to economic security. The search for mechanisms for ensuring the economic security of the state becomes a major task in the coming years. The solution of this problem is possible due to the development of certain algorithms of state management of economic security of the state on the basis of increasing the competitiveness of all sectors of the economy of Ukraine.

European integration is a way of transforming the economy of Ukraine, overcoming technological backwardness, attracting foreign investment and new technologies, creating new job opportunities, improving the competitiveness of domestic commodity production, entering the world markets, especially the EU one. In addition, in the long run, the EU membership will open the way to the joint security of collective structures of the European Union, will ensure more effective coordination of actions with European states in the field of economic security of Ukraine. Integration processes are complex ones themselves, therefore, it is necessary to understand what Ukraine needs for effective EU membership, what kind of problems may arise along the way, which factors need to be taken into account when designing plans, strategies and choosing a common integration vector for development. 


\section{LITERATURE REVIEW}

The European economic integration of Ukraine in the course of globalization of the world economy objectively strengthened the correlation and interdependence of processes occurring within the national economy and beyond its borders. Along with the benefits of participation in the international division of labor, the likelihood of unfavorable impact of external factors on the domestic economy has increased. As a consequence, in determining the priorities for the economic development of the country and developing an economic policy program, more attention should be paid to ensuring economic security of Ukraine as a member state of international economic relations.

The concept of security, borrowed from the theory of international relations, immanently refers to the systems in which the subjects of political decision-making function; this makes arguments about the "security" of industries, enterprises, etc. artificial. The concept of "national security" appeared in the political lexicon relatively recently. For the first time, the term "national security" was used in the 1904 message of US President Theodore Roosevelt to Congress (1908), where he justified the joining of the Panama Canal Zone with the interests of the "national security" of the United States. In 1947, the US Congress passed the law "On National Security" (1947), according to which the existing nowadays National Security Council has been created.

American political scientist A. Wolfers (1962) wrote: "Security, objectively, implies the absence of threats to acquired values. Subjectively, it means the lack of fears that these values will be damaged". From this definition it follows that safety is a necessary condition for the accumulation of values. Thus, it is one of the conditions for the successful functioning of any system and, therefore, a necessary condition for the formation and functioning of the institution of the state, separate regions and sectors, economic entities, etc. According to the concept by J. Keynes (1937), which was formed in the mid-1930s, the main threats to the country's economic security are not external competitors, but internal factors, in particular unemployment and economic depression. Therefore, the basic task of the government was the active regulation of economic activity by subsidizing depressed industries, placing state orders and providing subsidies, and introducing direct administrative control over competition.

According to I. Nikolaev et al (2003), economic security of the country, as a whole, can be guaranteed only if the degree of dependence of the country according to the established indicators (criteria) does not exceed a certain threshold, which may threaten national sovereignty. Another condition is the willingness and ability of the authorities to create such mechanisms for the implementation and protection of national interests of the domestic economy, which would maintain the socio-political stability of society at an appropriate level. D. Gordienko (2009) believes that economic security is a state of protection of the national economy from external and internal threats, in which it is able to ensure the progressive development of society, its economic and sociopolitical stability in the presence of unfavorable external and internal factors. The peculiarity of this definition lies in the fact that the author considers this category from the position of external and internal factors instead of integration of these factors. Consideration of problems of ensuring economic security is reasonable from the point of coordinating a conflict of interest. Thus, Z. Varnaliy (2011) has a slightly different point of view: "Economic security is a set of forms and methods for harmonizing the various interests of economic entities, which allows solving conflicts at the lowest cost and using the least destructive method for the economy". The most complete definition of economic security from the standpoint of macroeconomic development provides V. Heets (2006), who believes that the condition of the economy, society and institutions of government is economically safe when the implementation and guaranteed protection of national economic interests, progressive socio-economic development of the country are ensured.

Since in Ukraine at the end of 2018 martial law was declared in certain regions of the state, it is considered to be timely to analyze the categorical apparatus of the study from this very point. Thus, B. Gubskiy (2001) believes that economic security is an ability and readiness of the economy 
to provide adequate living conditions and development of the person, socio-economic and militarypolitical stability of society and the state, to counteract the influence of internal and external threats. Consideration of the problems of ensuring economic security is also possible from the standpoint of ensuring sustainable development. The issue is addressed in the works byA. Denisov (2014), who provides the following interpretation of this category: "Economic security is a state of the national economy that allows it to remain resistant to internal and external threats, to ensure high competitiveness in the global economic environment and characterizes the ability of the national economy to maintain stable and balanced growth".

An essential component of the state's economic security in the context of international integration is the social sphere. The social sphere is the most unprotected area, in which the risks from integration processes are very high. This point of view is supported by K. Zukrowska (2013), who gives the following interpretation: "The economic security of the state means the conditions for harmonious development, which makes it possible to build sustainable welfare of the citizens of the state. In terms of macroeconomic security, this is the stability of employment, low unemployment, and predictable prospects for economic development. In the microeconomic dimension it means the solvency of the business entity or business in general. In both cases, it means the ability to balance commitment with regard to the needs of the medium term".

The study will not be complete without an analysis of the existing views of European scientists on this issue. European scientists believe that the main vector of ensuring economic security is the optimal combination of economic factors of development. Thus, K. Ksiezopolski (2011) believes that the economic security of the state is the continuous functioning of the economy, which means maintaining the main indicators of development, as well as ensuring a comparative equilibrium with the economies of other countries. K. Raczkowski (2012) has a different view: "Economic security is a balanced state of the endo- and exogenous functioning of the national economy, in which the risk of disbalance occurs. The reduction of this risk requires the implementation of certain and approved organizational and legal norms and standards, the principles of social coexistence". It should also be noted that to ensure the economic security of Ukraine, a comprehensive analysis of all factors influencing this process is necessary. This idea is supported by E. Jurakovskiy (2016) with distinguishes the following mechanisms for ensuring economic security: production, tax, financial, credit, customs, investment, social, infrastructure, institutional, integration.

In conditions of the rapid pace of globalization and integration, the role of the state, as a regulating social institution, is getting more important. Historically, people have always united for the most effective and civilized provision of their own needs for security, food, etc. T. Hobbes (1655 / 1989-1991) argued that the state is a way out of the eternal struggle of all against all. However, today, the institution of the state, called primarily to lobby the interests of its own population, faces an ambiguous problem of either actively supporting the processes of globalization, thus allowing its own population to receive certain benefits (first of all, material) from this, or inhibiting the entry of the country's economy into a globalized world space, trying to preserve its sovereignty, national traditions, etc. The solution of this problem is possible only with the correct interpretation of the concept of "national security of the state" and the establishment of the components that ensure this security.

I. Filipishyn, L. Oliinyk and I. Vlasenko (2017) believe that the peculiarity and complexity of securing the country's economic security lies in that fact that its effectiveness greatly depends on the human factor. The condition of economic security of the state can be studied from the standpoint of stability. Thus, S. Kozlovskyi, I. Khadzhynov, I. Vlasenko and L. Marynchak (2017) consider that "the economic stability of the system is the ability of the economic system after a certain perturbation (changes in the parameters of the economic system, its indicators) to quickly return to the state not worse than the previous one, to maintain its condition as long as desired, as well as to improve its state to the size of the perturbation in case of positive changes in the economic parameters of the system". 
The concept of economic security of the state is directly connected with the processes of globalization and integration. Thus, Y. Shishkov (1979) understands integration as a process of interpenetration and coalescence of national (intra-country) reproduction processes in the broadest sense of their understanding. "The line separating integration from the lower stages of the internationalization of economic life, and the integration complex from the rest of the set of microeconomic links, passes where the production, technology, economic and politico-legal interdependence of national economies turns into interpenetration and intertwining of national reproduction processes." The history of economic integration is quite long. Still, there are two ways of economic integration objectively standing out: the creation and development of transnational companies and the creation of interstate unions. T. Malyarenko and S. Wolff (2017) believes that the conflict in the Donbas area of Ukraine, from this perspective, potentially foreshadows a more fundamental transformation of Russia's strategic behavior and illustrates how Russia may use different tactics of societal destabilization and covert occupation as a part of its military and security doctrine to manage a regional security complex that is critical to both its identity and ability to retain great power status and the capability to act globally.

S. Krupka (2007) believes that ensuring the economic security of Ukraine in the conditions of integration is possible based on of functioning and developing the capital market in Ukraine should become the pressure ofinvestment potential on renovation and the protectionof the enterprise growth. Y. Jianhua and D. Yichen (2012) states that in the traditional theory of economic security, the premise is the assumption of anarchy in international politics, and the actors of security are nation states. And it believes that nation states mainly achieve economic security through self-service behaviors. utočnit imena. Nowadays, when economic security is becoming one of the most important components of international, regional and national security, the European Union is beginning to play a leading role in ensuring the stability and security of the European continent. The process of building and reforming the EU must be considered not only as an extension of the "common market" boundaries, but also as a factor of the creation of a new European economic security structure with an integrated and interconnected nature. The main issue in the context of economic security in the case of Ukraine's integration into the EU is maximizing the potential benefits of participating in a multilateral trading system and minimizing the potential economic threats of joining it.

\section{METHODOLOGY}

The methodological basis of the research is the scientific works on the main aspects of ensuring the economic security of Ukraine in the context of European integration. Publications of domestic and foreign scientists in scientific professional periodicals, legal acts that regulate the principles of ensuring the economic security of Ukraine, compose the information and analytical basis of the study. The statistical base of the article has been prepared on the basis of official websites and reports of the State Statistics Service of Ukraine and reports of the World economic forum.

To achieve the goal of the study, the following general and special scientific methods and tools have been used: the abstract method, the logical method and the method of theoretical analysis have been applied to determine the essence of economic security; generalization method, system analysis, comparative analysis and abstraction have been exploited to study the existing methodological approaches to the definition of the main internal and external threats to the economic security of Ukraine in the context of European integration; graphic method - to illustrate certain problematic factors of doing business in Ukraine, to illustrate and analyze the index of global competitiveness of EU countries, to illustrate and analyze economic indicators of the volume of exports and imports between Ukraine and the EU countries in comparison with indicators of the level of foreign direct investment in the Ukrainian economy; the method of synthesis, concretization and analogy to determine the threshold level of economic security of Ukraine as well as to develop an algorithm 
for state management of economic security and to formulate conclusions and proposals for this study.

Descriptive statistical analysis methods were applied to organize the research results. It is obvious that the level of economic security is not a goal in itself, but, above all, a factor and a consequence of the high level of socio-economic development of the state and its place in the global (integration) economy. In order to verify the hypothesis expressed, we will present the results of the assessment of the relationship between the integral indicator of Ukraine's economic security and threshold values indicators of economic security of Ukraine, such as the volume of external debt; the share of external borrowings in covering the budget deficit; the share of export earnings spent on debt repayment; the ratio of the amount of cash foreign currency to the amount of cash hryvnia; shareof manufacturing productsin exports; share of high-tech productsin export; share of imports in domestic consumption. The aim of the study is to determine the main factors influencing the provision of economic security, and the improvement of the mechanism for managing the economic security of Ukraine in the context of European integration.

\section{RESULTS}

The main components of the economic security of the state are following: the country's geographical position, the level of state management of the economy, the reserves of natural resources, industrial potential, the level of agricultural production and the level of socio-demographic development, and integration processes. The main feature of integration, distinguishing it from other forms of political cooperation between countries, is the presence of supranational authorities, to which the member states of the association delegate a part of their sovereignty. In the process of integration, economic aspects are intimately intertwined with political and military ones. Integration affect the vital interests of participating countries, their international priorities and orientations, traditions and cultural values. Integration violates the level of economic security of the state in those aspects that are affected in the process of interstate agreement on economic issues. The priorities of Ukraine in the state economic policy aimed at rapprochement with the European Union has been greatly changed since 2014 . This integration aspiration has caused a change in the factors ensuring the economic security of the state and has led to the need to study these factors, threats and processes affecting the state of Ukraine's economic security. The unified state policy is necessary to achieve a scientifically sound level of economic security. The policy should be backed up by a system of coordinated measures that are adequate to the internal and external threats that may arise in the country. Without a well-designed and effectively implemented state policy of ensuring the country's economic security, it is impossible to get out of any crisis, to create effective mechanisms for social protection of the population and to manage the economic situation in the country as a whole and in its regions.

The integration of economic security of the country with international economic security should be one of the components of state policy. Currently, the legal framework regulating the provision of economic security of Ukraine consists of (Makara, 2013):

Constitution of Ukraine. It is stated in Art. 17 of the Constitution of Ukraine that protection of the sovereignty and territorial integrity of Ukraine, ensuring its economic and information security are the most important functions of the state, the business of the entire Ukrainian nation (Constitution of Ukraine, 1996).

Laws of Ukraine: "On National Security of Ukraine", "On the National Security and Defense Council of Ukraine", "On Prevention and Counteraction to Legalization (Laundering) of the Proceeds from Crime"; tax and currency legislation; the legislation of Ukraine on privatization, bankruptcy, foreign economic activity; The current Criminal Code, Criminal Procedure Code, Civil Code, Civil Procedure Code, Customs Code, Budget Code, Economic Code of Ukraine, etc., are directly related to the regulation of economic relations (Kurmaiev and Pyzhianova, 2017). 
Decrees and directives of the President of Ukraine.

Decrees and directives of the Cabinet of Ministers of Ukraine.

The core internal and external threats to the economic security of Ukraine based on the situation in the Ukrainian economy should be highlighted analyzing the trends observed in the process of the reform of this situation - Table 1. Also, the "Global Competitiveness" ratings, which is annually formed during the World Economic Forum (Davos), also testify the existence of certain threats to national economic security. Experts from this worldwide forum evaluate more than 150 countries of the world on two indicators - the index of potential growth and the index of competitiveness. If in 2013 Ukraine ranked 84th (out of 148 studied economies of the world), then by 2017 it had lost 11 positions, despite being ranked 38th in the size of the market, 43th in terms of higher education and 57 th on the level of secondary education.

The main problems of Ukraine, as stated in The Global Competitiveness Report 2016-2017, are low competitiveness of goods and services (124th place), as well as incomplete reforms in the banking and financial sectors (117th place). Using the research (Jurakovskiy, 2015; Predborskiy, 2005; Kurmaiev and Pyzhianova, 2017), one should classify the main internal threats to the economic security of Ukraine:

- absence of a developed concept and system of economic security at the state level;

- insufficient level of scientific and technical potential, loss of leadership in important areas of scientific and technological progress;

- high level of deterioration of the material and technical base of many economic sectors;

- unjustified liberalization of foreign economic activity;

- significant differentiation in income and consumption of the population, increase in poverty, high unemployment;

- anti-social policy in the sphere of privatization;

- the criminalization of the economy, the growth of its "shadow" sector and the high level of corruption in the state-management sector;

- imperfection of legislation in the field of economic relations and mechanisms of economic policy formation;

- lack of motivation to work, etc.

In the context of institutional changes, such as the integration of Ukraine's economy into the European Union, Ukraine faces the following external threats:

- reduction of investment revenues in the state economy;

- a significant proportion of raw material exports in foreign trade and the loss of traditional markets;

- the dependence of Ukraine's provision on the import of goods of everyday demand, technological products of strategic importance;

- acquisition by foreign firms of Ukrainian enterprises in order to eliminate them from external and internal markets;

- a critically high level of external debt of the country, etc.

For the recent years, competition of leading global and regional states-leaders has been intensified for the redistribution of spheres of influence, particularly in the post-Soviet countries. Ukraine's struggle for independence, as a non-aligned country, is taking place in complicated and dangerous conditions of the conflict of interests between the world most influential states. These external threats increase the negative impact of internal threats that arise within socio-political transformations in Ukraine, which has become an object of asymmetric political, economic, information pressure from the stronger states (Fleychuk, 2018). Thus, the development of Ukraine's economic activity is taking place in difficult geopolitical conditions. We can single out the following 
global threats that may arise when strengthening the integration processes of Ukraine along the path to European integration:

- threats caused by the geopolitical situation of the country (aggression, military-political conflicts, terrorism, etc.);

- threats caused by low level of economic power and competitive positions in the world market;

- threats of loss of competitive advantages in strategically important sectors, due to integration into the European economic space;

- threats caused by the unsustainable economic policy of the state regarding the determinants of competitive advantages, which reduces the level of the country's competitiveness;

- threats caused by the economic expansion of dominant economies and dominant militarypolitical alliances;

- threats caused by import intervention in the domestic markets of strategically important goods and services.

This has led to increasing negative impact of some external and internal threats. Such changes in the geopolitical situation have also opened new opportunities for the development of economic relations of Ukraine, in particular presenting domestic enterprises at new foreign markets and ensuring the conformity of domestic products to European or world standards. In order to withstand the pressure from the outside and in a timely manner to prevent the real external dangers and threats, they must be clearly identified. According to the data of World economic Forum (The Global Competitiveness Report 2016-2017), Ukraine is ranked 81st in the world in terms of the Global Competitiveness Index. Most problematic factors for doing business induced in the figure 1.

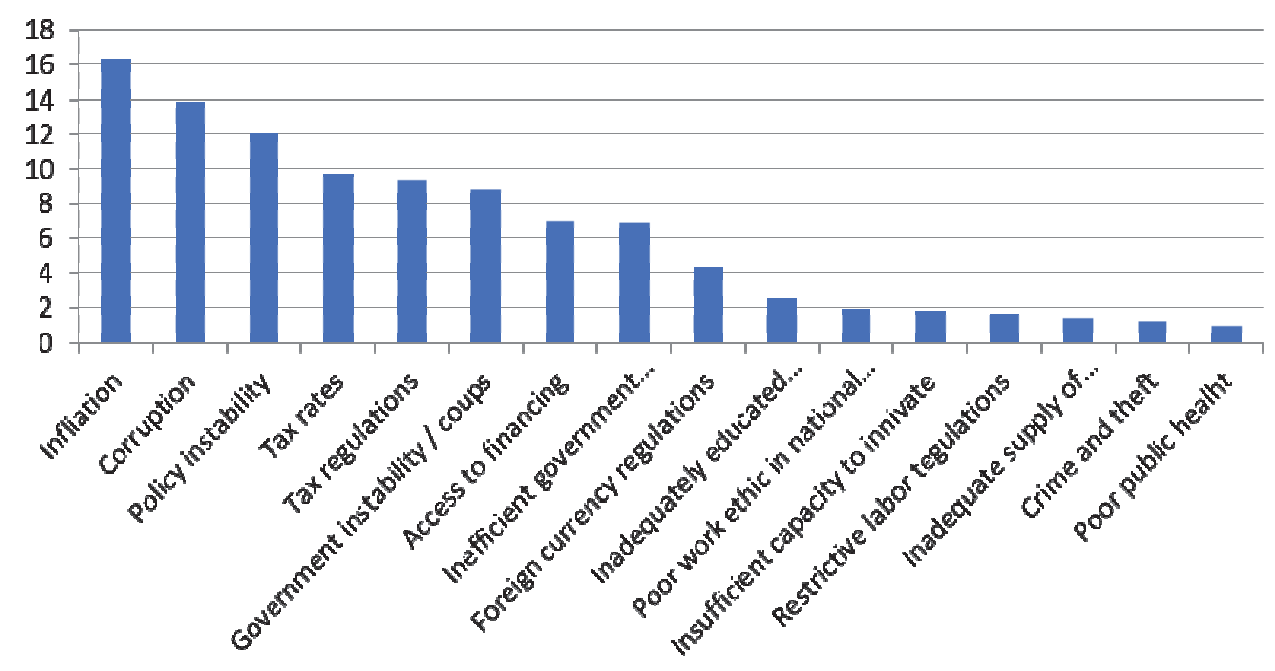

Figure 1. The most problematic factors for doing business in Ukraine on the path to European integration Source: compiled by the authors based on The Global Competitiveness Report 2017-2018, 2018.

For Ukraine, when integrating into european space, significant measures are needed to reduce inflation, corruption, reduce tax pressure, carry out a reform of public administration, and so on (see Fig/ 1). All these factors affect the overall level of economic security of the state. It is on these indicators that european institutions assess the state and level of economic development of Ukraine. If we analyze Ukraine's place on the global competitiveness index in comparison with the EU, we can state the following (Fig. 2). Unfortunately, Ukraine has an unsatisfactory level for this index. By the level of this indicator only Greece and Moldova are nearby. 


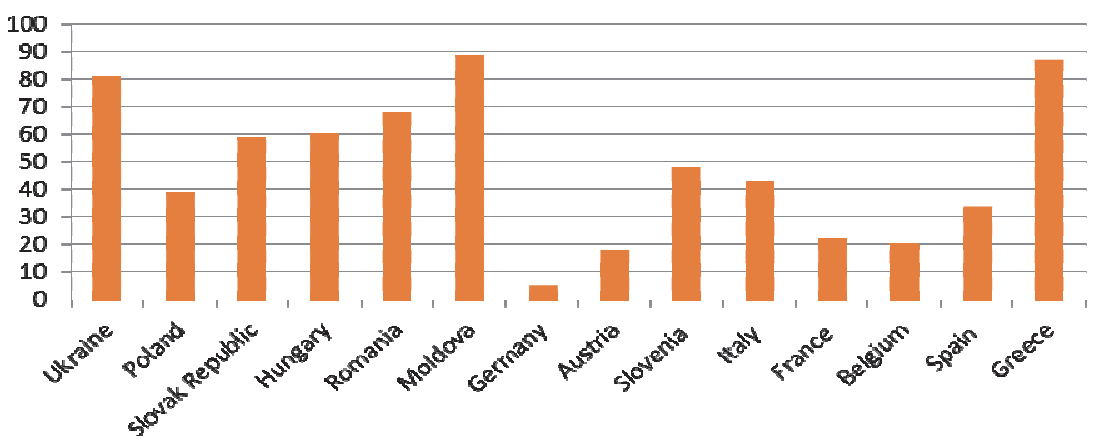

Figure 2. Indicators for the Global Competitiveness index 2017-2018 EU countries (set of indicators in three principal categories (subindexes) and twelve policy domains (pillars) for 137 economies)

Source: compiled by the authors based on The Global Competitiveness Report 2017-2018, 2018

The analysis of Figure 2 shows that Ukraine, along with such EU countries as Greece and Moldova, has the worst indicators of Global Competitiveness Index 2017-2018. To improve the Global Competitiveness Index, Ukraine needs to take the certain steps. Firstly, Ukraine must meet the Copenhagen criteria, such as: observance of democratic principles of human rights; the rule of law; the presence of a competitive market economy that is able to compete in the EU's domestic market; recognition of common EU rules and standards; adoption of a set of institutional and legal norms of European integration. Secondly, the stability of institutional structures, democracy and the rule of law must be ensured and guaranteed. However, nowadays, a slow implementation of reforms and corruption scandals bursting in the country can be observed. Moreover, all this is happening on the background of aggression in the Donbass and Russia's pressure to destabilize the situation in Ukraine, which is lowering the index level.

According to the authors the most serious threats to the integration of Ukraine into the european space, are following:

- a significant external debt and related increase in the cost of its repayment together withrisen attempts to use it as means of pressuring in making major economic and political decisions;

- the increasing taking by the foreign firms of the domestic market of Ukraine and, as a consequence, the growing dependence of country on the import of manytypes of goods including strategic ones;

- discriminatory measures of several international organizations and foreign countries in foreign economic relations with Ukraine, protectionist policy towards the country, displacement of Ukrainian enterprises from traditional foreign markets, especially military ones and markets of machine-building products;

- the acquisition by foreign firms of local enterprises in order to control them and create the conditions for their own success in competition, both on the external and internal markets;

- unsatisfactory condition of the customs border and insufficient export and currency control;

- undeveloped infrastructure of export-import operations, etc.

The main indicator for assessing the state of the country's economic security is the Gross Domestic Product (Fig. 3). The data of the fig.3 indicate that the level of Ukraine's economic security can be assessed as "negative." This conclusion is based on the fact that in Ukraine over the past three years the GDP level has decreased by $50.7 \%$. Such a decline in GDP is considered catastrophic for any economy. The decline in GDP in Ukraine was accompanied by a drop in the level of capital investment (fig. 3), a decrease in the population and a decline in household incomes, which amounted to more than $41.4 \%$ over the three-year period. All this shows serious problems in the national economy of Ukraine. The causes of these problems are following: a military component, anti-terror operation in the east of Ukraine and a change in the vector of national priorities. 


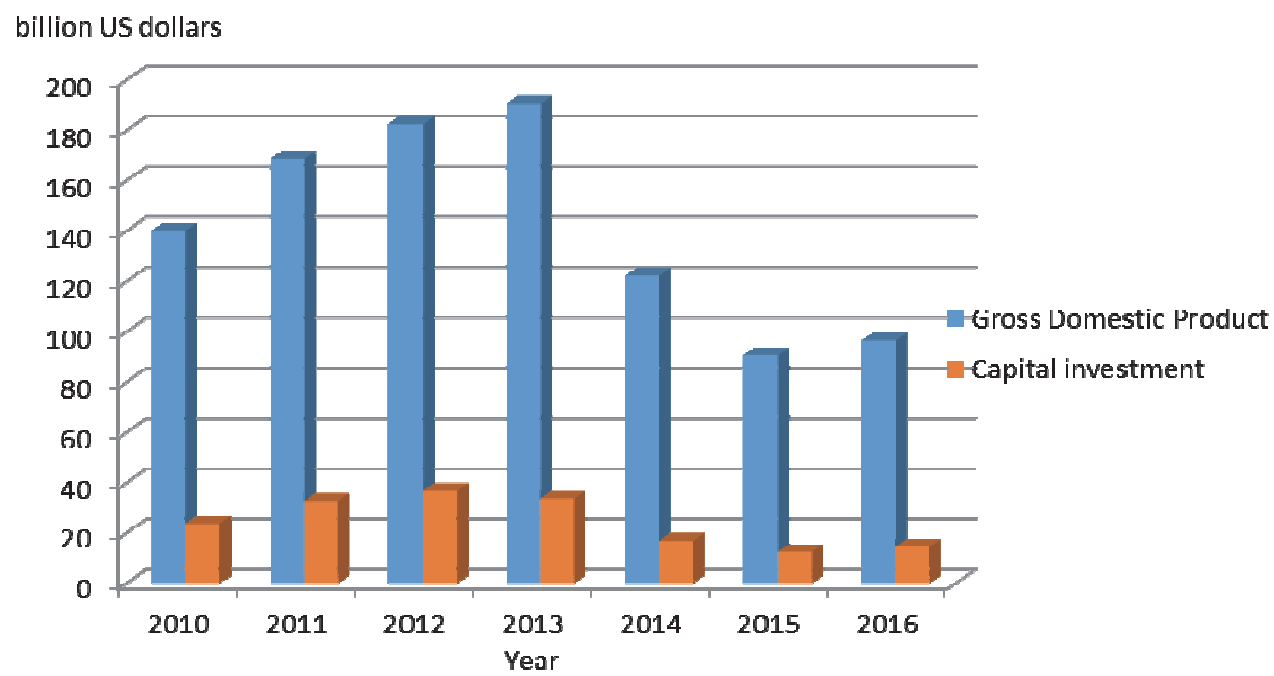

Figure 3. Dynamics of Gross Domestic Product and Capital Investment Level change in Ukraine (2010-2016)

Source: compiled by the authors based on State statistics service of Ukraine, 2018.

In order to evaluate the level of economic security of Ukraine in the conditions of European integration, it is expedient to use an assessment of the macroeconomic indicators of the country's development and determine the thresholds of these indicators. An increase in the level of economic security can be achieved only if all the indicators involved in evaluation are within the limits of acceptable thresholds. At the same time, the improvement of the acceptable value of one indicator should not be achieved at the expense of the decline of the value of another. For example, lowering inflation to the marginal level should not lead to an increase in unemployment above the permissible limit. The reduction of the state budget deficit to the threshold should not cause a full freezing of investments and the fall of production and so on.

Determination of all threshold values must begin with threshold values characterizing the social sphere. There are three key indicators in assessing the social position of the people: the share of the population with incomes below the subsistence minimum, richest $10 \%$ to poorest $10 \%$ ratio, the ratio of an average household income per member to the subsistence minimum. World experience shows that the danger of social conflicts is minimal if the share of the population living below the subsistence minimum is $7-10 \%$ and the gap between the income of the rich and the poor does not exceed 10 times. The experience of pre-reform decades, when the level of the last indicator did not exceed 4-5 times, should be considered.

In the process of developing a list of thresholds for indicators of economic security, some scientists raise the question of including a special index characterizing the development of human potential. This is about widely used since 1990 in the structures of the UN Human Development Index (HDI). It is now recognized in the world practice as the most accurate, generalizing indicator of social progress, personal security and development of the social sphere (Human Development Report, 2016). It is acknowledged in the world practice as the most accurate, generalizing indicator of social progress, personal security and development of the social sphere (Ibid.).

However, Ukraine does not possess he previous experience and a sufficiently developed statistical base for calculating the quantitative parameter of the threshold value for HDI. It may require a lot of time, to process the statistical base and calculation methodology for HDI. Therefore, the expert values of the threshold indicators of economic security of Ukraine will be determined on the basis of macroeconomic statistics of Ukraine - Table 1. 
Serhii Kozlovskyi, Roman Grynyuk, Viktoriia Baidala, Vira Burdiak and Yuriy Bakun / Montenegrin Journal of Economics, Vol. 15, No. 3 (2019), 137-153

Table 1. Indicators and threshold values of economic security of Ukraine

\begin{tabular}{|c|c|c|c|}
\hline Indicators & $\begin{array}{l}\text { Threshold value } \\
\text { (\% GDP) }\end{array}$ & $\begin{array}{l}\text { The value of the factu- } \\
\text { al indicator in Ukraine }\end{array}$ & $\begin{array}{l}\text { Possible social and economic consequences } \\
\text { of exceeding the threshold value }\end{array}$ \\
\hline The volume of external debt & 25 & 60 & $\begin{array}{l}\text { Dependence, interest payments, inhibition } \\
\text { of development }\end{array}$ \\
\hline $\begin{array}{c}\text { The share of external borrowings in } \\
\text { covering the budget deficit }\end{array}$ & 30 & 40 & Cutting off of protected budget items \\
\hline $\begin{array}{c}\text { The share of export earnings spent } \\
\text { on debt repayment }\end{array}$ & $15-20$ & 20 & The crisis of non-payments \\
\hline $\begin{array}{l}\text { The ratio of the amount of cash } \\
\text { foreign currency to the amount of } \\
\text { cash hryvnia }\end{array}$ & 25 & 300 & Hidden financing of a foreign state \\
\hline $\begin{array}{c}\text { Share of manufacturing productsin } \\
\text { exports }\end{array}$ & 40 & 10 & $\begin{array}{l}\text { The colonial and raw material structure } \\
\text { of the economy, the fall of professionalism }\end{array}$ \\
\hline Share of high-tech products in export & $10-15$ & 1 & Technological backwardness of the economy \\
\hline $\begin{array}{c}\text { Share of imports in domestic con- } \\
\text { sumption }\end{array}$ & 30 & 72 & $\begin{array}{l}\text { Dependence of the country on imports } \\
\text { in strategic spheres }\end{array}$ \\
\hline
\end{tabular}

Source: compiled by the authors

It is also important to determine the extent of the negative consequences of non-compliance with the quantitative parameters of the threshold values of economic security. It is necessary to rethink the classification of Ukraine's national interests in the economy, taking into account the geostrategic tasks of Ukraine, the experience of implementing the state strategy of economic security, and to assess new challenges and threats. Analyzing the spectrum of threats to economic security, one can come to the conclusion that at least two thirds of these threats are directly related to the problem of the competitiveness of the national economy and one third - to unsustainable economic policies in the social and environmental spheres. At the same time, a very significant part of threats in the social sphere is indirectly initiated by the level of competitiveness of the economy. The competitiveness of the national economy can be considered from the perspective of the volume of foreign trade - Fig. 4. The higher is the level of exports compared to imports the more competitive is the economy of the state. This factor indicates that the economic security of the state does not have a sustainable positive value.



Figure. 4. The volume of foreign trade of Ukraine with the EU countries (2015-2017)

Source: compiled by the authors based on State statistics service of Ukraine, 2018. 
Analyzing the share of exports and imports of Ukraine with the EU countries - Fig. 5, it can be concluded that Ukraine has a hidden economic potential in increasing exports to the EU.



Figure 5. Share of exports and imports of EU countries in total (2015-2017)

Source: compiled by the authors based on State statistics service of Ukraine, 2018.

This implies that the priorities of investment policy lie precisely in these areas of state economic security - Fig. 6. Unfortunately, direct investments in the economy of Ukraine, especially from the EU states, are very low. This shows the mistrust of a foreign investor, at the first place, and the lack of a positive economic climate in the country.



Figure 6. Direct investments into the economy of Ukraine, mln. USA (2015-2017)

Source: compiled by the authors based on State statistics service of Ukraine, 2018.

As it has been mentioned above, the question of determining the overall integral indicator of Ukraine's economic security is relevant for the country. It is possible to determine this index at the present time only in terms of its components (Fig. 7). In fig. 7 the components of the integral indi148

cator of Ukraine's economic security and the threshold values of these indicators adopted in 
the European Union are presented. One can see that the state of economic security of Ukraine in the process of integration into the EU is not yet satisfactory. According to most of the threshold values of the integral indicator of economic security, Ukraine has much worse value. To improve these indicators, it is necessary to change the priorities of the state's economic policy and develop a system for managing economic security.

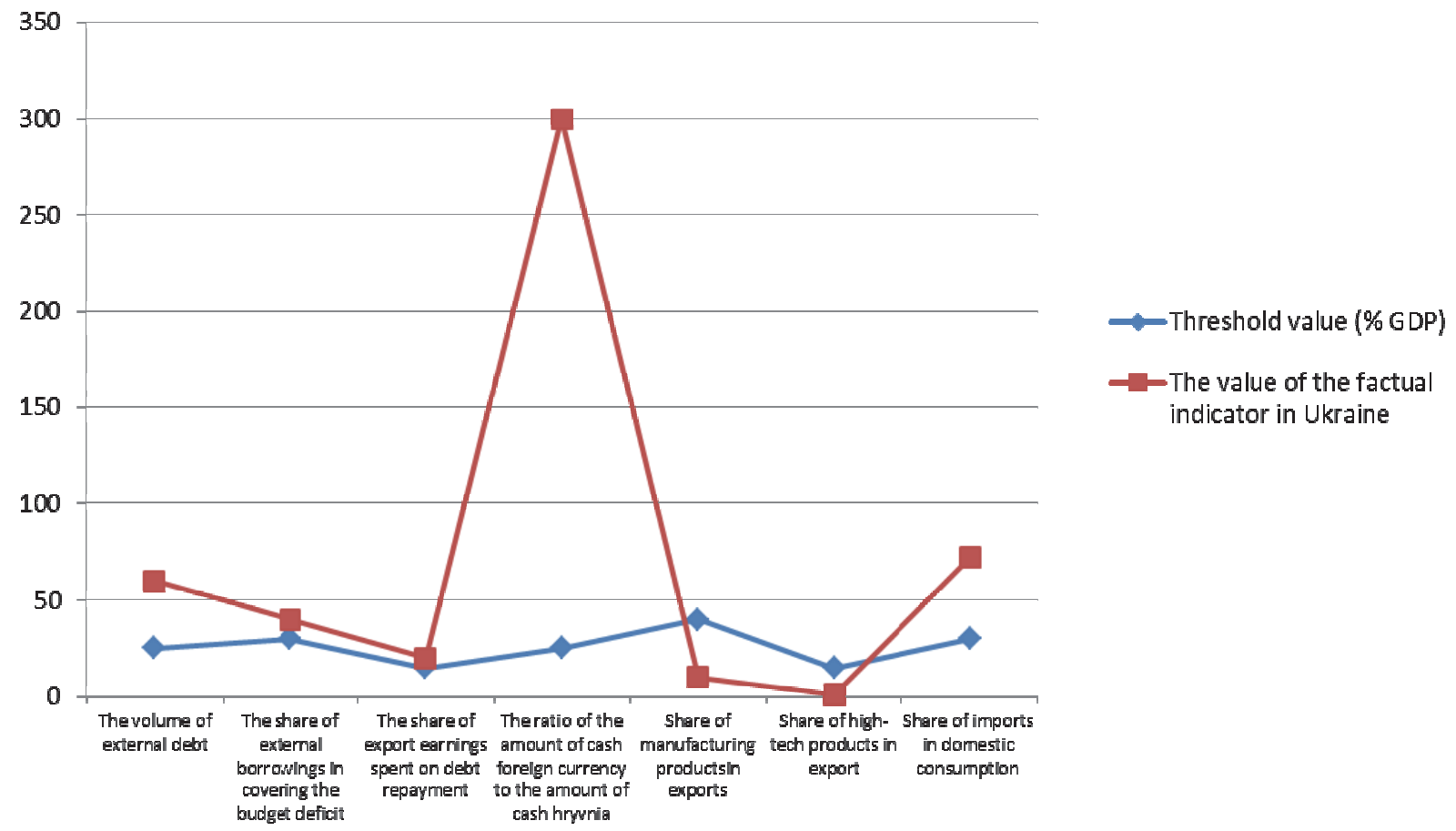

Figure 7. Indicators and threshold values of economic security of Ukraine

Source: compiled by the authors

Thus, Ukraine needs to change its economic policy to comply with the criteria of economic security of the state required by the EU. It should be emphasized that the process of European integration is associated with deep economic reforms, as well as radical institutional transformations, which entail certain economic losses and will require significant investment (Table 2).

Table 2. Economic advantages and disadvantages of Ukraine's integration into the EU

\begin{tabular}{|c|c|}
\hline Advantages & Disadvantages \\
\hline $\begin{array}{c}\text { Ensuring the development of small and medium-sized } \\
\text { businesses }\end{array}$ & Probable allocation of harmful productions in Ukraine \\
\hline Implementation of EU standards & Loss of competitiveness of certain industries \\
\hline Convergence of energy potentials of countries & The complexity of transition to the European level of prices \\
\hline Development of tourism and recreation industry & The worsening of economic relations with the CIS countries \\
\hline Boosting the production of certain industries & \\
\hline
\end{tabular}

Source: compiled by the authors

According to the results of the study, it can be determined that an analysis of approaches to ensuring economic security by the European Union countries indicates that this level of security is 
high enough and depends on a variety of factors. If Ukraine strives to preserve the domestic market and an independent economic future in the process of the EU integration, the country needs to go a long way to overcome the economic crisis. For this purpose, it is important to understand the concept of the essence of economic security and the precise and coordinated actions of authorized state bodies and structures to bring Ukraine's level of economic security closer to the European one. Based on everything that has been mentioned above, in order to reduce economic threats and increase Ukrian's competitiveness, an algorithm for transition from a resource-dependent export-oriented path to an import-substituting innovative path of development of Ukraine has been developed. This path will use the natural resource potential as a fund for accumulating and redistributing financial flows into the innovation sphere - Figure 8.

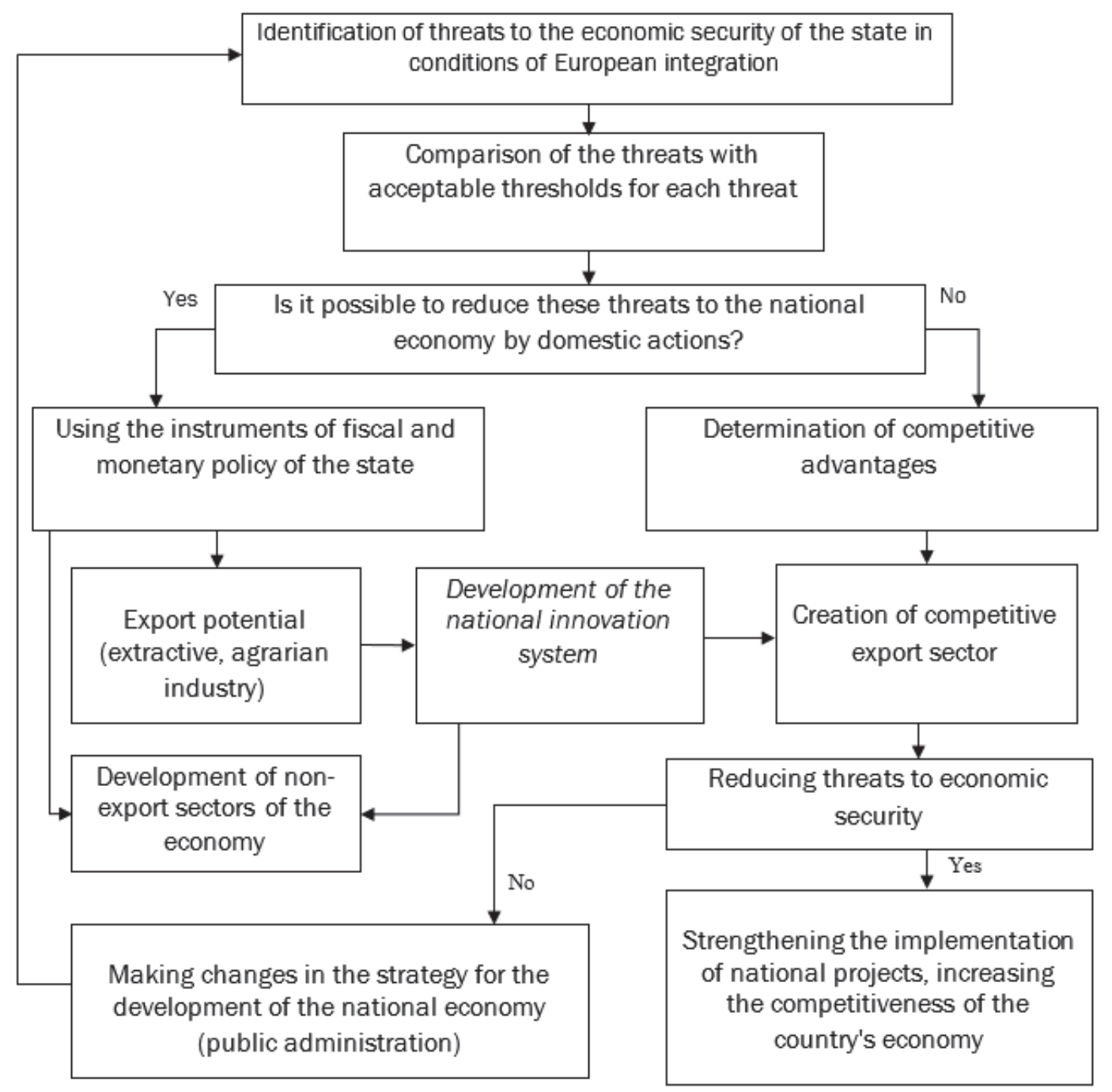

Figure 8. Algorithm of public management and regulation of economic security by increasing the country's competitiveness

Source: compiled by the authors

The national innovation system "must unite the efforts of public authorities of all levels, scientific and technical organizations and the business sector of the economy in order to accelerate the use of achievements of science and technology, that will help to implement the country's strategic 150

national priorities". Formation of a network of institutional tools for ensuring the production of 
innovative products and development of innovative infrastructure is necessary to solve the tasks.

The joint coordinated work on the concept of innovative development and the concept of economic security of Ukraine will allow to realize the competitive advantages of Ukraine in conditions of integration into the EU. According to the above-mentioned, the following conclusions can be drawn: European integration is an objective process that takes place at the level of the national economy, and individual actors cannot significantly affect it; European integration as an objective process has a combination of consequences for all spheres of life in Ukraine; the consequences of European integration form both opportunities and threats to Ukraine's economy; overcoming or neutralizing threats to economic security as a result of European integration opens up new opportunities for Ukraine, strengthens its positions (in the markets as well), and realization of threats, on the contrary, weakens it.

Nowadays, Ukraine is undergoing the third stage of European integration, which is characterized by the beginning of wide-ranging adaptation of Ukrainian legislation to EU norms and the need to increase the efficiency of civil society institutions' activities in order to monitor the implementation of the Association Agreement between Ukraine and the EU. Therefore, the European integration of Ukraine is extremely important for the formation of an effective mega-economic space of a stabilizing European economy. Defense of the choice of the strategic direction of cooperation at the mega-level in the conditions of the formation of a new socio-economic structure of Europe, the formation of a socially oriented market economy requires radical changes in the concept of creating approaches to forming the directions of ensuring economic security of Ukraine and the European Union as well at certain levels.

\section{CONCLUSION}

The economic security of Ukraine in conditions of integration into the EU is achieved, on the one hand, by increasing competitiveness in the domestic market. On the other hand, the adaptability of the national economy to the conditions of the world market also plays an important role in this process. It is necessary to use the competitive advantages of the national economy through the introduction of innovations. Liberalization of foreign trade and orientation to the EU market reduces the development of the domestic sector of the economy due to the lag in the technological and innovative development of Ukraine. The development of the domestic sector of Ukraine's economy is experiencing serious competition from imported goods. Thus, it is necessary to use the methods of state regulation in support of domestic production.

To ensure Ukraine's competitiveness and economic security, it is necessary to change the system of public administration by redistributing natural rents from extractive (agrarian) industries to innovative ones. It is needed since the existing market incentives and the current practice of reducing investments in the domestic sector, their accumulation in the export sector, cannot provide sustainable growth and competitiveness in the long term. The economic security of Ukraine in conditions of economic integration into the European economic system represents a condition of the economy and social sphere of the state, under which they are protected from the effects of internal and external threats caused by international and interstate relations and the processes of globalization. The European integration of the Ukrainian economy must consider the fact that the integration process is based on the international division of labor, which, in turn, is based on the specialization of individual economies in the production of certain types of products, which are subsequently exchanged between countries. The interaction of countries is characterized both by the level of their economic development, and by the degree of involvement in the world economy. Economic security will be strengthened by improving state regulation of economic growth by developing conceptual and programmatic documents for interregional and territorial planning, creating an integrated risk management system, including the following measures: 
- carrying out active state anti-inflationary, currency, exchange rate, monetary and fiscal policies aimed at import substitution and support for the real sector of the economy;

- stimulating and supporting the development of the innovation market, science-intensive products and products with high added value, development of promising technology of general, dual and special purpose.

Ensuring Ukraine's economic security in conditions of integration into the international economic space is a very difficult task. This task relates to the implementation of the country's socioeconomic development strategy, ensuring a stable balance of internal and external interests and defending its strategic and tactical interests, taking into account the interests of other countries.

Thus, it can be concluded that the basis for ensuring the economic security of the country is a constant and purposeful activity of the state to create the following necessary conditions:

- maintaining competitive advantages of the leading sectors of the national economy in foreign and domestic markets by improving and developing all the determinants of the "national rhombus" (the content of the category "national diamond" is given M. Porter and J. Heppelmann, 2017);

- reaching the European (international) level and quality of life of the population of the country, including considering the opposition to "ecological expansion".

In the process of further integration of Ukraine into the European community, the following

types of contradictions arise and need to be resolved: between the desire to expand the market for national production, co-operation and specialization of the economy using competitive advantages and the desire of the world economy of developed countries to keep Ukraine the status of a raw material appendage of a united Europe; between greater openness of the economy and increased international competition in the context of integration and the need to protect national security; between the short-term benefits of the current export structure and the weakness of market incentives to switch to trade in high-availability products; between the need for an innovative development path for Ukraine, as the most promising for economic growth and the country's competitiveness in the European space, and the current structure of the economy.

\section{REFERENCES}

Constitution of Ukraine (1996), avaible at: http://zakon.rada.gov.ua/go/254 k/96-вp.

Denisov, A. I. (2014), "The economic security of the state: the problem of economic and legal support", Bulletin of the National University "Law Academy", Vol. 2, pp. 197-206 (in Ukrainian).

Filipishyn, I., Oliinyk, L., Vlasenko, I. (2017), "Development of complex system for ensuring economic safety of agrarian sector of Ukraine", Problems and Perspectives in Management, Vol. 15(4), pp. 168-177. doi: 10.21511/ppm.15(4-1).2017.01.

Gordienko, D. V. (2009), Fundamentals of economic security of the state, Finance and Statistics, Moscow (in Russian).

Gubskiy, B. V. (2001), Economic security: measurement methodology, state and strategy of provision, Ukrarhbudinform, Kiev (in Ukrainian).

Heets, V. M. (2006), Innovative prospects of Ukraine, Konstanta, Kharkov (in Ukrainian).

Human Development Report 2016, United Nations Development Programme, avaible at: http://hdr.undp.org

Jurakovskiy, E. S. (2015), "The main internal and external threats to Ukraine's economic security", Contemporary Economic Science: Theory and Practice: Collection of the V Scientific-Practical Conference, PoltNTU, Poltava, pp. 136-138. (in Ukrainian).

Jurakovskiy, E. S. (2016), "Concept, tools and mechanisms for ensuring economic safety of the agrarian sector", Agrosvit, Vol. 6, pp. 68-72 (in Ukrainian).

Jianhua, Y., Yichen, D. (2012), Energy Politics and Security Conceptsfrom Multidimensional Perspectives, Journal of Middle Eastern and Islamic Studies (in Asia), Vol. 6(4), pp. 91-120, doi: 10.1080/19370679.2012.12023215. 
Keynes, J. M. (1937), "The General Theory of Employment", The Quarterly Journal of Economics, Vol. 51, No. 2, pp. 209-223.

Kozlovskyi, S., Khadzhynov, I., Vlasenko, I., Marynchak, L. (2017), "Managing the sustainability of economic system as the basis of investment development in Ukraine", Investment Management and Financial Innovations, Vol. 14(4), pp. 50-59. doi:10.21511/imfi.14(4).2017.06.

Ksiezopolski, K. M. (2011), Bezpieczeństwo ekonomiczne, Dom Wydawniczy ELIPSA, Warszawa.

Krupka, S. (2007), "Impact of the capital market on the transformation ofthe economy in Ukraine", Technological and Economic Development of Economy, Vol. 13(3), pp.198-203. doi.org/10.1080/13928619.2007.9637800.

Kurmaiev, P. Yu., Pyzhianova, N. V. (2017), "Organizational and economic mechanism of state regulation of higher education system in Ukraine», Scientific bulletin Polissya, Vol. 1(9), pp. 107112.

Makara, O. V. (2013), "Economic security as a factor of development of entrepreneurial activity in the system of formation of social orientations of the national economy", Scientific bulletin NLTU, Vol. 23.18, pp. 131-137 (in Ukrainian).

Malyarenko, T., Wolff, S. (2018), The logic of competitive influence-seeking: Russia, Ukraine, and the conflict in Donbas, Post-Soviet Affairs, Vol. 34(4), pp. 191-212. doi: 10.1080/1060586X.2018.1425083.

Nikolaev, I., Shulga, I., Artemiev, S., Kalinin, A. (2003), "Economy of benefits. Social benefits", Society and economics, Vol. 9, pp. 157-181 (in Russian).

Official website of the State Statistics Service of Ukraine, avaible at: http://www.ukrstat.gov.ua/.

Predborskiy, V. A. (2005), Economic security of the state, Kondor, Kiev (in Ukrainian).

Porter, M. E., Heppelmann, J. E. (2017), "Why Every Organization Needs an Augmented Reality Strategy", Harvard Business Review, November, pp. 46-62.

Raczkowski, K. (2012), Percepcja bezpieczeństwa ekonomicznego i wyzwania dla zarządzania nim w XXI wieku. Bezpieczeństwo ekonomiczne, Wyzwania dla zarządzania państwem, Wolters Kluwer, Warszawa.

Roosevelt, T. (1908), The Roosevelt Policy: Speeches, Letters and State Papers, Relating to Corporate Wealth and Closely Allied Topics, of Theodore Roosevelt, President of the United States. p. 2.

Shishkov, Y. V. (1979), Formation of the integration complex in Western Europe: trends and contradictions, Nauka, Moscow (in Russian).

The Global Competitiveness Report 2017-2018, World economic forum, avaible at: http://www3. weforum.org/docs/GCR2017-

2018/05FullReport/TheGlobalCompetitivenessReport2017\%E2\%80\%932018.pdf

Hobbes, T. (1989-1991), Compositions, (editor V. V. Sokolova), Misl, Moscow (in Russian).

Varnaliy, Z. S. (2011), Ukraine's Economic Security: Problems and Priorities for Strengthening, Znannia Ukraini, Kiev (in Ukrainian).

Wolfers, A. (1962), nazvanie???, Johns Hopkins University Press, Baltimore. 